\title{
EXPRESSION OF OB GENE CODING THE PRODUCTION OF THE HORMONE LEPTIN IN HEPATOCYTES OF LIVER WITH STEATOSIS
}

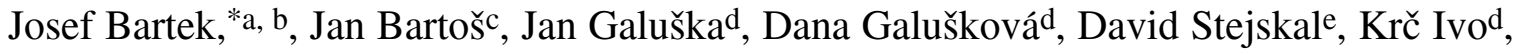 \\ Jiří Ehrmannd, Jiří Ehrman Jr. ${ }^{d}$, Rudolf Chlup ${ }^{d}$
}

\author{
a Institute of Medical Chemistry and Biochemistry, Palacký University Olomouc \\ b Institute of Immunology, University Hospital Olomouc \\ c BioVendor Brno Czech Republic \\ d 2nd Clinic of Internal Medicine, University Hospital Olomouc \\ e Department of Laboratory Medicine, Hospital Sternberk \\ $\mathrm{f} \quad$ Institute of Pathological Anatomy, Palacký University Olomouc
}

Received January 5, 2001

Key words: Expresion of ob gen / Leptin / Leptin receptor / Steatosis / Hepatocytes / PCR / ELISA

Leptin is a circulating pleiotropic hormone that play an important role in appetite control, fat metabolism, regulation of body weight, fetus growth, growth and aging of adults and hematopoiesis. It is expressed abundantly and specifically in the adipose tissue. A liver cell with developed steatosis represents a cell metabolism similar to metabolism of cells of adipose tissue. Analyses of serum leptin and free leptin receptor in the serum of patients with steatosis showed significant variations from reference limits of normal values. However in liver tissue with verified steatosis detection of mRNA gene for leptin was not proven. Such expression of ob gene for leptin was not found even in the liver tissue without steatosis. With respect to the absence of ob gene expression, the direct effect of ob gene expression on other parameters of leptin metabolism could not be evaluated. The RT-PCR method with verified specificity and satisfying sensitivity was developed. The results obtained from analysis of serum leptin and free leptin receptor in the serum are presented and evaluated. The used methods were verified and reference limits for Czech population were defined in dependence on age and other clinical parameters.

\section{INTRODUCTION}

Leptin is a circulating hormone that is expressed abundantly and specifically in the adipose tissue. A gene named $o b$ (obese) determines the protein sequence. The mouse $o b$ gene was discovered in 1994 through positional cloning ${ }^{34}$. Human ob genes have been localized to chromosome $7 \mathrm{q} 31.3^{17,20,34}$. The $o b$ gene encompasses $650 \mathrm{~kb}$ and consists of 3 exons separated by 2 introns. The coding region for leptin is located in exons 2 and 3 . The $o b$ gene encodes a 4.5-kilobase mRNA which is processed to 504 bp long mature RNA. Analysis of the $o b$ gene product revealed characteristics consistent with a secreted protein. After translation and processing of 21 aminoacids long signal, $16 \mathrm{kDa}$ protein consisting of 146 amino acid residues, is produced.

Several regulatory elements have been identified within the $o b$ gene promoter, e.g. cAMP and glucocorticoid response elements, and CCATT/enhancer and SP-1 binding sites $^{14}$. The sites responsible for adipose-specific expression and for regulated expression in responses to changes in adipose size and energy balance have not been identified yet. Regulation of adipose leptin expression by hormones and other factors is likely to be mediated by these DNA sequences $^{2}$.

Leptin is synthesized mainly, but not exclusively by white adipose tissue and is considered to play an important role in appetite control, fat metabolism and regulation of body weight. There is a strong positive correlation between leptin mRNA and protein levels in adipose tissue and circulating leptin levels $9,12,19,23,25$. So far, it is not known whether leptin is secreted by constitutive or regulated mechanisms; however, the former means is thought to be more likely because leptin does not appear to be stored in substantial amounts ${ }^{4}$. Available information confirms that leptin affects a lot of functions of peripheral target tissues - liver, pancreas, kidney, bone marrow, cells of blood vessels, ovaries, lung. It affects fetus growth, growth and aging of adults, hematopoiesis. It is a pleiotropic hormone ${ }^{13,18}$

Leptin expression is influenced by the status of energy stores in fat, as evidenced by increased adipose $o b$ mRNA and serum leptin levels in obese humans and other mammals $9,12,23$. Moreover, adipocyte size is an important determinant of leptin synthesis, as larger adipocytes contain more leptin than smaller adipocytes in the same individual ${ }^{15}$. Leptin levels in blood correlate with total body fat stores 9 , 12, 23. Leptin levels increase within hours after a meal in rodents and after several days of overfeeding in humans ${ }^{16,29}$. Leptin levels decrease within hours after initiation of fasting 29 .

Regulation of leptin expression by nutrition is probably mediated in part by insulin. Leptin expression increases after peak insulin secretion during the feeding cycle 29,31 . Leptin is decreased in low insulin states and increases after insulin treatment ${ }^{22}$. In human leptin expression is correla- 
ted with insulin levels, increases several days after insulin infusion, and may be predictive of insulin resistance ${ }^{6,30}$.

In rodents fasting, cold exposure, $\beta 3$-adrenergic receptor antagonists, and the insulin sensitising agent troglitazone decrease expression of leptin mRNA in adipose tissue and adipose cell lines from rats and mice, whereas feeding, dexamethasone, and insulin increase expression ${ }^{27}$. Short fasting reduced leptin mRNA expression in adipose tissue of prepubertal heifer ${ }^{3}$.

Leptin levels are regulated by other factors. Glucocorticoids directly stimulate leptin synthesis in cultured adipocytes ${ }^{10}$. Leptin expression increases in response to chronic elevation of cortisol in humans ${ }^{8}$. In contrast to this positive relationship, plasma leptin and glucocorticoid levels are inversely related ${ }^{21}$. Leptin levels are higher in prepubertal rodents and boys and do not appear to be dependent on adipose mass or triglyceride level. The prepubertal increase in leptin expression precedes the rise in testosterone and estradiol and is postulated to be involved in the maturation of the gonadal axis ${ }^{24}$. Females have higher leptin levels ${ }^{36}$ than males when matched by age, weight, or body fat. This may be attributable to sex differences in body fat distribution and testosterone level ${ }^{28}$. Subcutaneous adipose tissue is more abundant and contains higher levels of leptin in females. Leptin synthesis is inhibited by testosterone but is not affected by ovarian sex steroids ${ }^{5}$. Administration of thyroid hormone decreases leptin levels in rodents ${ }^{11}$.

Leptin synthesis is stimulated by infection, endotoxin, and cytokines ${ }^{1}$.

Initial studies indicated that leptin expression was synthesized only in adipose tissue. However, leptin is also synthesized in extra-adipose tissues including placenta, gastric fundic mucosa, skeletal muscle, and mammary epithelium ${ }^{1}$. A possible presence of leptin in human stomach has been reported ${ }^{32}$. Leptin expression in rat cerebral cortex, cerebellum, hypothalamus and anterior pituitary has been confirmed ${ }^{33}$.

\section{MATERIALS}

Expression of ob gene coding the production of the hormone leptin, i.e. detection of mRNA gene for leptin in human liver tissue was performed in the set of 10 samples of liver biopsy with liver steatosis documented by biopsy and explicit sonography. As a control comparative material was used excision from liver tissue of a proband without pathological finding in the histological and laboratory examinations. The bioptic and section sample was directly at the site of removal washed by a cooled physiological solution and then several sec. after removal was kept in the aluminium foil in liquid nitrogen. Such a stored sample was immediately after excision, several months after biopsy, subjected to analysis for detection of mRNA gene for leptin.

Characteristics of liver biopsies: 10 patients ( 2 women, 8 men) with liver steatosis, mean age of 46.7 years. Diabetes mellitus was diagnosed in $60 \%$. According to case history, alcohol abuse was present in $40 \%$. We examined the classical liver tests, lipids, and glycemia, BMI, body fat $\%$. Serum leptin concentrations and free leptin receptor in the serum were determined with the following results: serum leptin concentration was increased in $60 \%$, decreased in $10 \%$, mean value was $8.86 \mathrm{ng} / \mathrm{ml}$, variation was $1.9-17.3$ $\mathrm{ng} / \mathrm{ml}$. The level of free leptin receptor was increased in 60 $\%$, decreased in $20 \%$, mean was $58.17 \mathrm{U} / \mathrm{ml}$, variation of $26,2-101 \mathrm{U} / \mathrm{ml}$. The ratio of serum leptin/ leptin receptor in the serum was 0.19 on average. The limit for serum leptin was according to Nystrom (1997), the limit for leptin receptor according to Bartek (2000) $)^{38}$. Mean BMI was 28.7, ratio of serum leptin/ BMI was 0.30, transaminases (ALT) were increased in $70 \%$, bilirubin was increased in $20 \%$, alkaline phosphatase (ALP) was increased in $10 \%$, mean fat content in the body was $25 \%$. Cholesterol increased in $70 \%$, mean value was $5.72 \mathrm{mmol} / \mathrm{l}$. Triacylglycerols were increased in $30 \%$, mean value was $2.99 \mathrm{mmol} / \mathrm{l}$.

Characteristics of the control sample of liver tissue: man, 48 years. Histological finding in the tissue and laboratory examination in the serum were identical with the set of biopsies within the limits. Analysis of the mean fact content in the body was not performed.

\section{METHODS}

\section{Isolation of total mRNA from tissue}

To obtain good preparations of eukaryotic mRNA, it is necessary to minimize the activity of RNAases liberated during cell lysis using inhibitors of RNAases. By RNeasy Mini Kit (QIAGEN) following the instruction of supplier, total RNA was isolated from tissue. Briefly, to release all the RNA contained in the samples we disrupted cells walls and plasma membranes by grinding $20 \mathrm{mg}$ of the frozen material to a fine powder under liquid nitrogen. We transferred the suspension into a liquid-nitrogen-cooled tube and allowed the liquid nitrogen evaporate without allowing the sample to thaw. Homogenisation was done by QIAshredder - the lysate was loaded onto spin column, spun for $2 \mathrm{~min}$. at maximum speed and the homogenized lysate was collected. The total RNA from the lysate was binding onto silica-gel-based membrane washed and eluted using solutions from the kit.

Alternatively a manual method ${ }^{7}$ was used.

Briefly: The cells walls were disrupted and the RNA was released by grinding $20 \mathrm{mg}$ of the frozen material to a fine powder under liquid nitrogen. We have added denaturing solution with $\beta$-mercaptoetanol and transferred the suspension into RNase free centrifugation bottle. Then 20ul of $2 \mathrm{M}$ sodium acetate $(\mathrm{pH}=4), 200 \mathrm{ul}$ of phenol $(\mathrm{pH}=4.3)$ and $40 \mathrm{ul}$ of chloroform: isoamylalcohol mixture (49:1) was added. The same volume of DEPC water was added and the mixture was carefully but thoroughly mixed for 10 s, then left stand for 15 min on ice. Aqueous phase with RNA was separated by centrifugation $10000 \mathrm{~g} / 20 \mathrm{~min} / 4^{\circ} \mathrm{C}$. RNA was precipitated by equal volume of isopropanol at 60 $\mathrm{min} /-20^{\circ} \mathrm{C}$. Residual ions and salts were washed by $75 \%$ ethanol. The resulting RNA was dissolved in DEPC-water.

The isolated RNA was stored at $-70^{\circ} \mathrm{C}$ in DEPC-water. Denaturing-agarose gel electrophoresis and ethidium bromide staining checked the integrity and size distribution of total purified RNA. Usually 2 bands, corresponding $28 \mathrm{~S}$ and $18 \mathrm{~S}$ rRNA were visible. 


\section{Preparation of cDNA}

There are three ways to prime the mRNA for cDNA synthesis. In the first, a 3'(antisense) gene-specific primer is annealed to the mRNA and extended with reverse transcriptase. This generates a specific cDNA template for the 5 '(sense) primer. In the second and third methods, the entire population of mRNA molecules is converted into cDNA by priming with oligo(dT) or random hexamers. Two gene-specific primers are then added for amplification. With the latter two methods, several different genes can be amplified from the same pool of cDNA when primed with random hexamers or oligo(dT) primers.

We started with olido(dT) priming, which was found to be more sensitive and on average to yield fewer non-specific PCR products than random priming. We used 1st-strand cDNA Synthesis Kit (Clontech). The total RNA was denatured at $70^{\circ} \mathrm{C}$ for $2 \mathrm{~min}$., cooled immediately and reversetranscribed using 200 units of MMLV reverse transcriptase, 10 units of ribonuclease inhibitor, 100 pmol of poly(dT) primer and 10nmol of dNTP in a total volume of 20ul at $42^{\circ} \mathrm{C}$ for $1 \mathrm{~h}$. Enzyme was inactivated by heating at $94^{\circ} \mathrm{C}$ for $5 \mathrm{~min}$. The resulting cDNA molecules were stored at $-70^{\circ} \mathrm{C}$ before next using.

\section{PCR for housekeeping G3PDH gene}

The efficiency of the cDNA synthesis was estimated by using primers for amplification housekeeping gene for glycerol-3-phospho dehydrogenase. The absence of a specific band 983bp long suggests that a component of the cDNA synthesis reaction or PCR reaction was omitted. PCR was carried out in the final volume $20 \mu \mathrm{l}$ consisting of $2 \mu \mathrm{l}$ of cDNA, 10 pmol of each primer and 17,8 $\mu$ l HotStarTaq DNA Polymerase Mix Kit(QIAGEN). DNA samples were first denatured completely by incubation at $94^{\circ} \mathrm{C}$ for $3 \mathrm{~min}$ before the amplification cycle then DNA was amplified by subjecting it to 25 cycles of (i) denaturation at $94^{\circ} \mathrm{C}$ for $45 \mathrm{sec}$, (ii) primer annealing at $60^{\circ} \mathrm{C}$ for $45 \mathrm{~s}$, and (iii) elongation at $72^{\circ} \mathrm{C}$ for $2 \mathrm{~min}$, using a Thermocycler (model MJ Research PTC150). After the last amplification cycle, the samples were further incubated at $72^{\circ} \mathrm{C}$ for 3 min for complete elongation of the final PCR products. After the PCR, the amplification results were visualized by performing $1-1,2 \%$ agarose gel electrophoresis in (voltage: $5 \mathrm{~V} / \mathrm{cm}$; time: 30-45 min) 1x TBE buffer and ethidium bromide staining. As a marker was used 100bp ladder.

\section{Amplification for ob gene}

Primers for leptin were chosen to cross an intron/exon boundary to ensure that the amplified product was not derived from genomic DNA. Consequently, samples were amplified in the absence of reverse transcriptase to establish the maximum number of cycles, which could be used while minimizing DNA contamination.

PCR was carried out in the final volume $20 \mu \mathrm{l}$ consisting of $2 \mu \mathrm{l}$ of cDNA, $10 \mathrm{pmol}$ of each primer and 17.8 $\mu$ l HotStarTaq DNA Polymerase Mix Kit(QIAGEN).

Amplification was done with the primers based on sequence $o b$ (obese) gene (Acc No. D49487, ) resulting in a 547bp specific PCR product.
The following primers were used:

LEP2 (2-21): 5' - cttcttgggaaggaaaatgc - 3'

LEP530 (528-549): 5' - tagtcttgcaggaagagtgacc- 3'

As a positive control, 250fg cDNA from human placenta containing specific sequence and a negative control, sterile water, were included in each PCR. DNA samples were first denatured completely by incubation at $94^{\circ} \mathrm{C}$ for $5 \mathrm{~min}$ before the amplification cycle then DNA was amplified by subjecting it to 40 cycles of (i) denaturation at $94^{\circ} \mathrm{C}$ for $30 \mathrm{~s}$, (ii) primer annealing at $58^{\circ} \mathrm{C}$ for $30 \mathrm{~s}$, and (iii) elongation at $72^{\circ} \mathrm{C}$ for $1 \mathrm{~min}$, using a Thermocycler (model MJ Research PTC150). After the last amplification cycle, the samples were incubated further at $72^{\circ} \mathrm{C}$ for $5 \mathrm{~min}$ for complete elongation of the final PCR products. After the PCR, the amplification results were visualized by performing $1.2 \%$ agarose gel electrophoresis(voltage: $5 \mathrm{~V} / \mathrm{cm}$; time: 30-45 min) in 1x TBE buffer and ethidium bromide staining. As a marker was used 100bp ladder.

\section{Control cDNA preparation}

The coding sequence of the ob (obese) gene (Acc No. D49487, , position 2-549) was amplified and cloned to multiple cloning site polylinker of pUC18-T vector. In short, 10ul of ligation mixture (amplicon $+\mathrm{T}$-vector) was incubated overnight at $14^{\circ} \mathrm{C}$ and $3 \mathrm{ul}$ of the mixture was then heat-shock transformed into bacterial cells Escherichia coli DH5 $\alpha$, that were used for propagation of plasmid constructs. Screening of bacterial colonies for the presence of specific inserts was performed by specific PCR using sequencing primers M13 forward (-40) and M13 reverse for the plasmid pCR2.1. The presence of insert in the vector was indicated by the length of amplicons, which was longer than the $219 \mathrm{bp}$ - length of amplicon after amplification from empty vector pUC18. The presence of specific primer sequences in the constructs was confirmed by amplification by specific primers (see above). Mini-scale isolation of specific recombinant plasmid DNA was used for the preparation of recombinant plasmid for sequencing. The presence of specific sequences in the vector pUC18 was also confirmed by sequencing. The molecule is double-stranded circle, $3233 \mathrm{bp}$ in length. The length of the gene insert is $547 \mathrm{bp}$.

\section{Laboratory examination of patients}

The level of serum leptin and of free (soluble) leptin receptor in the serum (i.e. extracellular binding domain of leptin receptor) was determined by ELISA method 35 (BioVendor). Analyses of ALT, bilirubin, glucose, ALP, cholesterol and triacylglycerols were made by kits ROCHE on an analyzer HITACHI 917. Percentage of body fat was determined by the apparatus Omron BF 302. The steatosis was diagnosed in specimens fixed in $10 \%$ phosphate buffered formalin, processed by standard histological methods, embedded in paraffin and stained by haematoxylin-eosin . 


\section{RESULTS}

\section{Isolation of total mRNA from tissues}

From 20mg of tissue approximately 8-40ug of RNA was isolated, in dependence of tissue. The best material from this point of view was human placenta. The worst results were received from the fat cells. Gel electrophoresis of RNA isolated from different human tissues is demonstrated in Fig. 1.

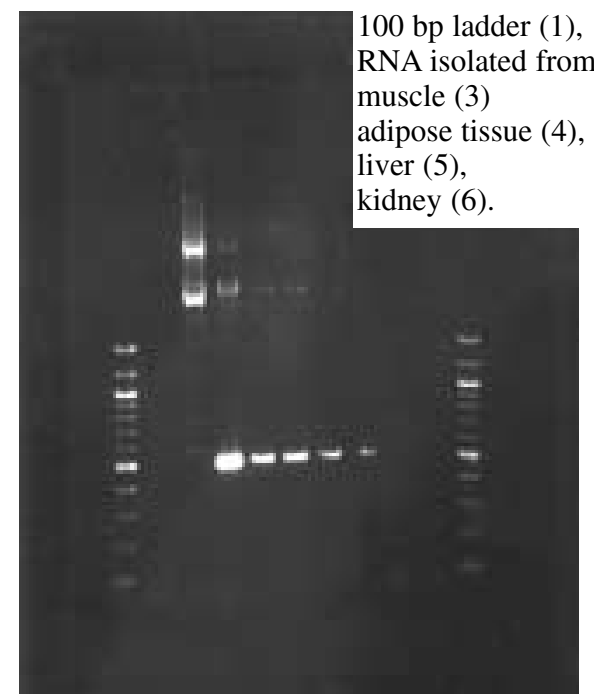

$\begin{array}{llllll}1 & 2 & 3 & 4 & 5 & 6\end{array}$

Fig. 1: Gel electrophoresis of RNA isolated from human tissues

\section{cDNA preparation and control PCR for G3PDH}

Usually $0,2-1,0$ ug of total RNA were used in reversion transcription. The efficiency of the cDNA synthesis was estimated PCR on housekeeping gene for glycerol-3phospho dehydrogenase. The specific $983 \mathrm{bp}$ long band results in all tissues - see Fig. 2.

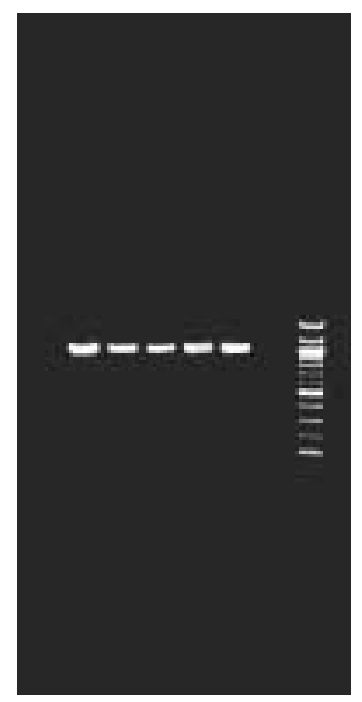

Specific 983bp long fragment: from placenta (1), muscle (2), adipose tissue (3), liver (4), kidney (5), negative amglification control (6), 100bp ladder (7). $\begin{array}{lllllll}1 & 2 & 3 & 4 & 5 & 6 & 7\end{array}$

Fig. 2: Gel electrophoresis of PCR for G3PDH

\section{Sensitivity of PCR}

Our system was tested to define the amount of recombinant plasmid molecules that should be added to PCR mixture so that visible amplicon can be identified on agarose gel. We found such amplicon when $10^{3}$ molecules of recombinant plasmid were used in the PCR. This amount represents sensitivity of our amplification - see Fig. 3. The PCR reaction was completely inhibited by DNA in concentrations over $55 \mathrm{ng} / \mathrm{ul}$.

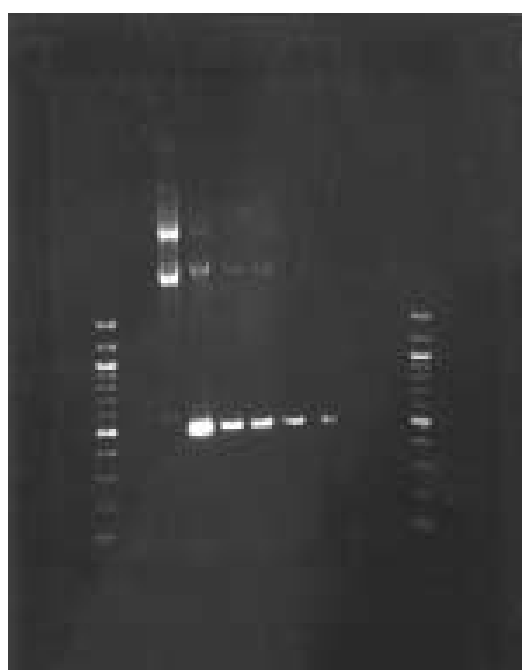

Specific 547bp long fragment: 100bp ladder (1), negative amplification control (2),

number of recombinant plasmid molecules $10^{8}$ (55ng/reaction) (3), $10^{7}(4), 10^{6}(6), 10^{4}(7)$ $10^{3}(8), 10^{2}(9), 10^{1}(10)$, 100bp ladder (11)

$\begin{array}{llllllllllll}1 & 2 & 3 & 4 & 5 & 6 & 7 & 8 & 9 & 10 & 11\end{array}$

Fig. 3: Sensitivity of PCR - amplification from recombinant plasmid

\section{Detection of $o b$-mRNA in tissues}

Using our amplification system, we were able to identify specific amplicon in placenta, fat cells and from skeletal muscle. No signal was received when liver and kidney were used as a source of RNA. We received 2 times higher yield when the manual method was used for isolation of RNA from fat cells. For isolation from the other tissue the RNeasy Mini Kit (QIAGEN) yielded in higher amount RNA. No pseudogen was amplified in any tissue.

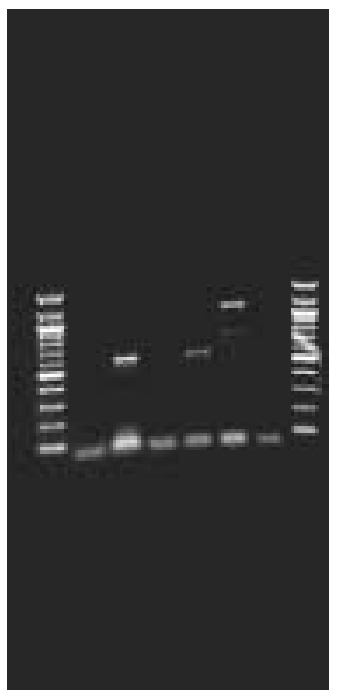

Specific 547bp long fragment: 100 bp ladder (1), negative amplification control (2), Amplification from human tissues: placenta (specific fragment) (3), muscle (negative) (4) adipose tissue (specific fragment) (5), liver (nonspecific fragments) (6), and kidney (negative) (7), 100bp ladder (8). $\begin{array}{llllllll}1 & 2 & 3 & 4 & 5 & 6 & 7 & 8\end{array}$

Fig. 4: PCR detection of ob -gene in human tissues 
In the studied set of liver biopsies of patients with verified liver steatosis, no transcript of ob gene was demonstrated even in the control material of liver tissue without pathological finding. Therefore it is concluded that we did not find expression of ob gene coding the production of leptin in hepatocytes of liver with steatosis even in the sample of liver without pathological finding.

\section{DISCUSSION}

Correlations between ob gene expression and steatosis and correlation between leptinemia and free leptin receptor have not been reported in the literature. Expression of ob gene for leptin is mostly situated in adipose tissue with the effect of leptin particularly on control of food intake, fat regulation and regulation of body mass. Other localisation of ob gene expression and other possible effects of leptin ${ }^{38}$ were documented. A liver cell with developed steatosis represents a cell metabolism similar to metabolism of cells of adipose tissue.

In liver tissue with verified steatosis, we did not proved detection of mRNA gene for leptin; such expression of ob gene for leptin was not found even in the liver tissue without steatosis. However, in the absence of ob gene transcript, liver samples showed the presence of non-specific transcripts whose correct identification could be provided by analysis of sequences. Interesting enough is the finding that non-specific transcripts do not occur also in other tissues with negative expression of ob gene (Fig. 4). Analyses of serum leptin and free leptin receptor in the serum of patients with steatosis show significant variations from reference limits of normal values. However, with respect to the absence of ob gene expression, the direct effect of ob gene expression on other parameters of leptin metabolism cannot be evaluated.

The most promising the methodological aspect is the presented method with verified specificity (Fig. 2) and satisfying sensitivity of 1000 molecules of recombinant plasmid (Fig. 3). The removal of bioptic material and immediate freezing in liquid nitrogen minimise false negative results.

The results obtained from analysis of serum leptin and free leptin receptor in the serum are presented and evaluated. The authors verified the used methods ${ }^{35}$ and for Czech population defined the reference limits in dependence on age $^{38}$ and on other clinical parameters ${ }^{36}$.

\section{ACKNOWLEDGEMENT}

The study was supported by the grant IGA MZ / M8-3.

\section{REFERENCES}

1. Ahima, R. S., Flier, J. S. (2000) Leptin. Annu. Rev. Physiol. 62, 413-437.

2. Ahima, R. S., Saper, C. B., Flier, J. S., Elmquist, J.K. (2000) Leptin regulation of neuroendocrine systems. Front. Neuroendocrinol. 21, 263-307.

3. Amstalden, M., Garcia, M. R., Williams, S. W., Stanko, R. L., Nizielski, S. E., Morrison, C. D., Keisler, D. H., Williams, G. L. (2000) Leptin gene expresion circulating leptin and luteinizing hormone pulsatility are acutely responsive to short-term fasting in prepubertal heifers: relationship to circulating insulin and insulin-like growth factor I(1). Biol. Reprod. 63, 127-133.

4. Barr, V.A., Malide D, Zarnowski, M.J., Taylor, S.I., Cushman, S.W. (1997) Insulin stimulates both leptin secretion and production by rat white adipose tissue. Endocrinology 138, 4463-4472.

5. Blum, W.F., Englaro, P., Hanitsch, S., Juul, A., Hertel, N. T., Muller, J., Skakkebaek, N. E., Heiman, M. L.,Birkett, M., Attanasio, A. M., Kiess, W., Rascher, W. (1997) Plasma leptin levels in healty children and adolescents: dependence on body mass index, body fat mass, gender, pubertal stage and testosteron. J. Clin. Endocrinol. Metab. 82, 2904-2910.

6. Boden G., Chen X., Kolaczynski J. W., Polansky M. Effects of prolonged hyperinsulinemia on serum leptin in normal human subjects. J Clin Invest 100: 1107-13, 1997. Boden, G., Chen, X., Kolaczynski, J. W., Polansky, M. (1997) Effects of prolonged hyperinsulinemia on serum leptin in normal human subjects. J. Clin. Invest. 100, 1107-1113.

7. Chomczynski, P., Sacchi, N. (1987) Single-step method of RNA isolation by acid guanidinium thiocyanate-phenol-chloroform extraction. Anal. Biochem. 162, 156-159.

8. Cizza, G., Lotsikas, A. J., Licinio, J., Gold, P. W., Chrousos, G. P. (1997) Plasma leptin levels do not change in patients with Cushings disease shortly after correction of hypercortisolism. J. Clin. Endocrinol. Metab. 82, 2747-2750.

9. Considine, R. V., Sinha, M. K., Heiman, M. L., Kriauciunas, A., Stephes, T. W., Nyce, M. R., Ohannesian, J. P., Marco, C. C., McKee, L. J., Bauer, T. L. (1996) Serum immunoreactive-leptin concentrations in normal-weight and obese humans. N. Engl. J. Med. 334, 292-295.

10. De Vos, P., Saladin, R., Auwerx, J., Staels, B. (1995) Induction of ob gene expression by corticosteroids is accompanied by body weight loss and reduced food intake. J. Biol. Chem. 270, 5958-5961.

11. Escobar-Morreale, H. F., Escobar, D. R., Morreale, D. E. (1997) Thyroid hormones influence serum leptin concentrations in the rat. Endocrinology 138, 4485-4488.

12. Frederich, R. C., Hamann, A., Anderson, S., Lollmann, B., Lowell, B. B., Flier, J. S. (1995) Leptin levels reflect body lipid in mice: evidence for diet-induced resistance to leptin action. Nat. Med. 1, 1311-1314.

13. Friedman, J. M., Halaas, J. L. (1998) Leptin and the regulation of body weight in mammals. Nature 395, 763-770.

14. Gong, D. W., Pratley, R. E., Weintraub, B. D. (1996) Genomic structure and promoter analysis of the human obese gene. J. Biol. Chem. 271, 3971-3974.

15. Hamilton, B. S., Paglia, D., Kwan, A. Y., Deitel, M. (1995) Increased obese mRNA expression in omental fat cells from massively obese humans. Nat. Med. 1, 953-956.

16. Harris, R. B., Ramsay, T. G., Smith, S. R., Bruch, R. C. (1996) Early and late stimulation of ob mRNA expression in meal-fed and overfed rats. J. Clin. Invest. 97, 2020-2026.

17. He, Y., Chen, H., Quon, M. J., Reitman, M. (1995) The mouse obese gene. Genomic organization, promoter activity, and activation by CCAAT/enhancer-binding protein alpha. J. Biol. Chem. 270, 28887-28891.

18. Houseknecht, K. L., Baile, C. A., Matteri, R. L., Spurlock, M. E. (1998) The biology of leptin: a review. J. Anim. Sci. 76, $1405-1420$.

19. Hwang, C.S., Mandrup, S., MacDougald, O.A., Geiman, D.E., Lane, M.D. ( 1996) Transcriptional activation of the mouse obese (ob) gene by CCAAT/enhancer binding protein alpha. Proc. Natl. Acad. Sci. USA 93, 873-877.

20. Isse, N., Ogawa, Y., Tamura, N., Masuzaki, H., Mori, K., Okazaki, T., Satoh, N., Shigemoto, M., Yoshimasa, Y., Nishi, S. (1995) Structural organization and chromosomal assignment of the human obese gene. J. Biol. Chem. 270, 27728-27733.

21. Licinio, J., Mantzoros, C., Negrao, A. B., Cizza, G., Wong, M. L., Bongiorno, P. B., Chrousos, G. P., Karp, B., Allen, C., Flier, J. S., Gold, P. W. (1997) Human leptin levels are pulsatile and inversely related to pituitary- adrenal function . Nat. Med. 3, 575-579.

22. MacDougald, O. A., Hwang, C. S., Fan, H., Lane, M. D. (1995) Regulated expression of the obese gene product (leptin) in white 
adipose tissue and 3T3-L1 adipocytes. Proc. Natl. Acad. Sci USA 92, 9034-9037.

22. Maffei, M., Fei, H., Lee, G. H., Dani, C., Leroy, P., Zhang, Y., Proenca, R., Negrel, R., Ailhaud, G., Friedman, J. M. (1995) Increased expression in adipocytes of ob RNA in mice with lesions of the hypothalamus and with mutations at the $\mathrm{db}$ locus. Proc. Natl. Acad. Sci. USA 92, 6957-6960.

24. Mantzoros, C. S., Flier, J. S., Rogol, A. D. (1997) A longitudinal assessment of hormonal and physical alterations during normal puberty in boys. V. Rising leptin levels may signal the onset of puberty. J. Clin. Endocrinol. Metab. 82, 1066-1070.

25. Miller, S. G., De Vos, P., Guerre-Millo, M., Wong, K., Hermann, T., Staels, B., Briggs, M. R., Auwerx , J. (1996) The adipocyte specific transcription factor C/EBPalpha modulates human ob gene expression. (1997) Proc. Natl. Acad. Sci. USA 93, 5507-5511.

26. Ogawa, Y., Masuzaki, H., Isse, N., Okazaki, T., Mori, K., Shigemoto, M., Satoh, N., Tamura, N., Hosoda, K., Yoshimasa,Y. (1995) Molecular cloning of rat obese cDNA and augmented gene expression in genetically obese Zucker fatty (fa/fa) rats. J. Clin. Invest. 96, 1647-1652.

27. Pratley, R. E., Ren, K., Milner, M. R., Sell, S. M. (2000) Insulin increases leptin mRNA expression in abdominal subcutaneous adipose tissue in humans. Mol .Genet. Metab. 70, 19-26.

28. Rosenbaum, M., Nicolson, M., Hirsch,. J., Heymsfield, S. B. Gallagher, D., Chu, F., Leibel, R. L. (1996) Effects of gender, body composition, and menopause on plasma concentrations of leptin. J. Clin. Endocrinol. Metab. 81, 3424-3427.

29. Saladin, R., De Vos, P., Guerre-Millo, M., Leturque, A., Girard, J., Staels, B., Auwerx, J. (1995) Transient increase in obese gene expression after food intake or insulin administration. Nature $377,527-529$.
30. Segal, K. R., Landt, M., Klein, S. (1996) Relationship between insulin sensitivity and plasma leptin concentration in lean and obese men. Diabetes 45, 988-991.

31. Sinha, M. K., Ohannesian, J. P., Heiman, M. L., Kriauciunas, A., Stephens, T. W., Magosin, S., Marco, C., Caro, J. F. (1996) Nocturnal rise of leptin in lean, obese, and non-insulin-dependent diabetes mellitus subjects. J. Clin. Invest. 97, 1344-1347.

32. Sobhani, I., Bado, A., Vissuzaine, C., Buyse, M., Kermorgant, S., Laigneau, J. P., Attoub, S., Lehy, T., Henin, D., Mignon, M., Lewin, M. J. (2000) Leptin secretion and leptin receptor in the human stomach. Gut 47, 178-183.

33. Wilkinson, M., Morash, B., Ur, E. (2000) The brain is a source of leptin. Front. Horm. Res. 26, 106-125.

34. Zhang, Y., Proenca, R., Maffei, M., Barone, M., Leopold, L., Friedman, J. M. (1994) Positional cloning of the mouse obese gene and its human homologue. Nature 372, 425-432.

35. Jedelský, J., Bartek, J., Stejskal, D. (1998) Leptin (ELISA). Fons 1, 38-40.

36. Stejskal, D., Růžička, V., Novák, J., Jedelský, L., Bartek, J., Horalík, D. (1998) Vyšetření leptinu v séru u žen v druhém trimestru gravidity. Vnitřní lékařství 44, 593-597.

37. Stejskal, D., Bartek, J., Růžička V., Stejskal P., Jedelský, P., Oral, I., Horalík, D., Žurek, M. (1999) Determination of leptin receptor in the serum and relations to laboratory and anthropological parameters in patients with atherosclerotic complications. Acta Univ. Palacki. Olomuc., Fac. Med. 142, 89-92.

38. Bartek, J., Stejskal, D., Stejskal, P., Oral, I. (2000) Concentration of soluble leptin receptor in population. Acta Univ. Palacki. Olomuc., Fac. Med. 144, 7-9. 